ENTREPRENEURSHIP AND SUSTAINABILITY ISSUES

ISSN 2345-0282 (online) http://jssidoi.org/jesi/

2020 Volume 7 Number 4 (June)

http://doi.org/10.9770/jesi.2020.7.4(53)

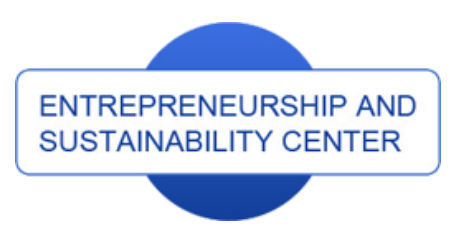

Publisher

http://jssidoi.org/esc/home

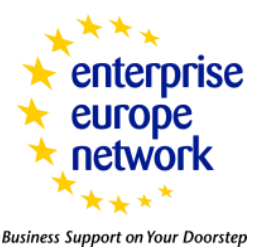

CASPA

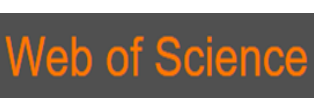

1) Clarivate

\title{
LEGAL OBSTACLES TO FREEDOM TO CONDUCT A BUSINESS: EXPERIENCE OF THE SLOVAK REPUBLIC ${ }^{*}$
}

\author{
Mária Srebalová ${ }^{1}$, Matej Horvat ${ }^{2}$, Juraj Vačok ${ }^{3}$, František Vojtech ${ }^{4}$, Stanislav Filip ${ }^{5}$ \\ ${ }^{1,2,3}$ Comenius University in Bratislava, Faculty of Law, Department of Administrative and Environmental Law, Slovak \\ Republic \\ ${ }^{4,5}$ School of Economics and Management in Public Administration in Bratislava, Slovak Republic
}

E-mails: ${ }^{1}$ maria.srebalova@flaw.uniba.sk; 2 matej.horvat@flaw.uniba.sk; ${ }^{3 j u r a j . v a c o k @ f l a w . u n i b a . s k ; ~}$

${ }^{4}$ frantisek.vojtech@vsemvs.sk; ${ }^{5}$ stanislav.filip@vsemvs.sk

Received 18 October 2019; accepted 15 March 2020; published 30 June 2020

\begin{abstract}
The paper focuses on legal obstacles affecting freedom to conduct a business in the Slovak Republic. It points out the freedom to conduct a business with regards to the Slovak and European perspective and compares it with the legal conditions laid down for starting a business pursuant to the Slovak legal regulation. The analysis especially orientates to define general conditions for natural persons and legal persons to be met in order to start a business, but also to describe special conditions, i.e. the requirements for qualification. The paper focuses on all persons who want to conduct a business in the Slovak Republic. Since the freedom to conduct a business is not necessarily related to citizenship, the paper analyses conditions laid to aliens. The general conditions to conduct a business are: a minimum age, a full legal capacity, and integrity of natural persons or representatives of legal persons. The obstacles to conduct a business are shown through analysis related to the main legislative problems and the article is giving several proposals for more business friendly legal regulation.
\end{abstract}

Keywords: freedom to conduct business; general conditions to conduct business; special conditions to conduct business; obstacles to freedom to conduct a business in Slovakia

Reference to this paper should be made as follows: Srebalova, M., Horvat, M., Vačok. J., Vojtech, F., Filip, S. 2020. Legal obstacles to freedom to conduct a business: experience of the Slovak Republic. Entrepreneurship and Sustainability Issues, 7(4), 3385-3394. http://doi.org/10.9770/jesi.2020.7.4(53)

JEL Classifications: A10, F2, K1, K22

Additional disciplines: law

\footnotetext{
* This paper was supported by the project, which has received funding from the Grant Research Agency of the School of Economics and Management in Public Administration in Bratislava, of the Slovak Republic.
} 


\section{ENTREPRENEURSHIP AND SUSTAINABILITY ISSUES}

ISSN 2345-0282 (online) http://jssidoi.org/jesi/

2020 Volume 7 Number 4 (June)

http://doi.org/10.9770/jesi.2020.7.4(53)

\section{Introduction}

The European Union faces a number of problems and challenges at present, concerning the economic development too. The fulfilment of fundamental rights can help to achieve the strategic goals set out in the Europe 2020 growth strategy and they should be mainstreamed throughout the most important European Union policies, which include ensuring the free movement of people, goods, services and capital within the internal market. See Directive 2006/123/EC of the European Parliament and of the Council of 12 December 2006 on Services in the Internal Market. The Directive is implemented by Act No. 136/2010 Coll. On Services in the Internal Market that amended Act No. 455/1991 Coll. Trade Licensing Act. The connection between economic growth and the fulfilment of the freedom to conduct a business is considerable (European Union Agency for Fundamental Rights, 2015). Business environment of "Old Europe" is examined (Begovič, B, 2018). He underlined, that economic freedom is somewhat curtailed, and that there are still important legal barriers of the competition policy. Therefore trust in public policy is reexamined by some authors (e.g. Lincényi, Čársky, 2020). As a one of many legal obstacles of economic growth examined also by (Petersen, N., 2007). His analyzes shows whether antitrust law actually has a positive effect on democracy and economic growth. Very inspirative for authors, were results of the specific examination about relationship between law and economic research provide by researcher from Harward Law School (Gurrrea-Martinéz, A, 2018).

The freedom to conduct a business is guaranteed by Article 16 of the Charter of Fundamental Rights of the European Union. The provision is worded as follows: "The freedom to conduct a business in accordance with Community law and national laws and practices is recognised." The freedom to conduct a business is a fundamental right. It is derived from the case law of the Court of Justice of the European Union and it was inspired by the national laws of European Union Member States (Sobihard et al., 2010). Its main aim is to safeguard the right of each person in the European Union to pursue a business without being subject to either discrimination or disproportionate restrictions. See for instance judgement of Court of Justice of the European Union, case 230/78, Eridania and others, 27 September 1979, paragraphs 20-22. It is a complex right and according to the relevant case law of the Court of Justice of the European Union it consists of the freedom to exercise an economic or commercial activity, the freedom of contract and free competition (Vrabko et al., 2012). The right to conduct a business is therefore one of the main rights related to the European Union. Basically, it is one of the cornerstones for existence of this European organisation. We shall focus on how this fundamental right (protected by many international treaties and European Union itself) is perceived in Slovak legislation and weather there are any issues to resolve in order to make business environment more open in the Slovak Republic.

\section{Research Process}

\subsection{Freedom to conduct a business in the statutes of the Slovak Republic}

The Slovak Republic protects and supports the freedom to conduct a business via Article 35 of the Constitution of the Slovak Republic (hereinafter only as Constitution). Under the Article 35 (1) of the Constitution everyone has the right to a free choice of profession and to training for it, as well as the right to engage in entrepreneurial or other gainful activities.

Besides the sources of the European law and the Constitution, we have to take into account Slovak national law on the statutory level. Basic legislative conditions for conducting a business stipulate Act No. 513/1991 Coll. Commercial Code as amended (hereinafter only as Commercial Code), Act No. 455/1991 Coll. Trade Licencing Act as amended (hereinafter only as Trade Licencing Act) and several other regulations laid down by special acts (such as various tax related statutes, statutes relating to the accounting systems, etc.). The Commercial Code defines business as a systematic activity carried out independently under a persons' own name and liability with 


\section{ENTREPRENEURSHIP AND SUSTAINABILITY ISSUES}

ISSN 2345-0282 (online) http://jssidoi.org/jesi/

2020 Volume 7 Number 4 (June)

http://doi.org/10.9770/jesi.2020.7.4(53)

the purpose of making a profit. Generally, foreign persons can conduct a business in the Slovak Republic under the same conditions and to the same extent as Slovak citizens. Therefore, there are no special regulations laid down to aliens; statutes perceive aliens as citizens (Magurová et al., 2016). However, this applies only to the citizens of the European Union, not to the citizens of non-European Union Member States.

According to the Commercial Code, an entrepreneur is:

a) a person registered in the Companies Register,

b) a person conducting business under a sole proprietorship, (A Slovak word ,živnost“" could be translated as trade also. However, we believe that the word "sole proprietorship" is more suitable and express better the very meaning of the word "živnost". On the other hand, the act that regulates sole proprietorship in the Slovak Republic is usually translated as Trade Licencing Act. We will hold this translation when it comes to this act in the text.)

c) a person conducting a business based on an authorization other than a sole proprietorship pursuant to a special act,

d) a natural person engaged in agricultural production that is registered in a register pursuant to a special act.

To conduct a business pursuant to the Trade Licencing Act means to conduct a systematic activity carried out independently under a persons' own name and liability with the purpose of making a profit under the conditions laid down in the Trade Licencing Act. An entrepreneur is obliged to carry out the sole proprietorship in accordance with the conditions stipulated in the Trade Licencing Act and by special regulations; obligations such as to carry out the sole proprietorship properly, honestly and with professional care (Škultéty et al., 2008). The sole proprietorship is not carried out properly, honestly and with professional care if low-quality goods and services are repeatedly provided based on breaching special regulations, especially standards and professional practices.

There is only one type of sole proprietorship in the Slovak Republic - notifiable sole proprietorship. The Trade Licencing Act distinguishes three subtypes of notifiable sole proprietorships: a) unqualified, b) vocational, and c) professional.

An entrepreneur according to the Trade Licencing Act can be a natural person or a legal person (hereinafter only as person). A person has to meet all general conditions that are laid towards all groups of sole proprietorships: a minimum age of 18 years, a full legal capacity and no criminal record (integrity of a person). Trade Licencing Act requires meeting special conditions also. They are laid towards vocational and professional sole proprietorship only. They relate with education and practice - professional or other qualification.

To start conducting any sole proprietorship a person (applicant, future entrepreneur) has to notify District Authority and then that person can conduct sole proprietorship pursuant to the Trade Licencing Act (Vrabko et al., 2015). There are 72 District Authorities throughout the Slovak Republic. Recently (since 2010), the Slovak legislation established all District Authority as so-called Points of Single Contact. Thus, organized authorities make administrative proceedings less bureaucratic and lengthy. Decision-making process and administrative proceedings concentrate in one place that is in front of the District Authority and the District Authority provides all necessary formalities needed for issuing authorisation for sole proprietorship. In his notification, applicant provides all the data necessary for a) requesting an extract from the criminal record, b) registration in the system of mandatory health insurance, and c) registration with the tax office.

\subsection{Analysis of distinguishing between types of sole proprietorship}

There are no significant problems in legal practice when it comes to the proceedings conducted by District Authority. Whether the applicant has met all the required conditions laid down by the Trade Licencing Act or not, 


\section{ENTREPRENEURSHIP AND SUSTAINABILITY ISSUES}

ISSN 2345-0282 (online) http://jssidoi.org/jesi/

2020 Volume 7 Number 4 (June)

http://doi.org/10.9770/jesi.2020.7.4(53)

does not cause any considerable problems. However, there are problems that exist in the very procedure of distinguishing between different kinds of sole proprietorships. In several cases, it is very hard to distinguish between sole proprietorship and several other liberal (free) professions, e.g. advocates, executors, artists, architects, etc.

As we already mentioned, there are three types of sole proprietorships in the Slovak Republic: unqualified, vocational and professional. Trade Licencing Act does not list any examples of unqualified sole proprietorships. It only stipulates that the list of unqualified sole proprietorships has to be published via web-page of the Ministry of Interior of the Slovak Republic (Ministry of Interior of the Slovak Republic (2016, 1 September). The List of Recommended Unqualified Sole Proprietorships and Their Descriptions http://www.minv.sk/?zivnostenskepodnikanie\&subor=40259)

The List of Recommended Unqualified Sole Proprietorships and Their Descriptions (hereinafter only as the List) is updated regularly, though the last update was conducted in September 2016. This List is not an enclosed list, but is only demonstrative. It is important to notice that the List is not legally binding. It has only a recommendatory character. Applicants therefore face situations in which one District Authority issues an authorisation for sole proprietorship while other one District Authority does not. The legal practice is not certain when it comes to sole proprietorships that fit all the general conditions of sole proprietorships, but as of now are not named on the List.

On the other hand, the Trade Licencing Act itself lists both other types of sole proprietorships (vocational and professional). The list of vocational sole proprietorship (e.g. development and production of weapons or ammunition; optics; dental technology; driving instructor; manufacture of tobacco products, etc.,) and professional sole proprietorship (e.g. stonemasonry; butcher shop; masonry; carpentry; chimney cleaning and inspection, etc.) is stipulated in the appendix of this Act (cf. Škultéty et al., 2002). This list is enclosed which means that a) no other sole proprietorship is professional or vocational and b) if a person's business is not on that list, then his business is unqualified sole proprietorship. In other words, regarding the character of sole proprietorship it is not possible to establish all unqualified sole proprietorships. According to the Trade Licencing Act the unqualified sole proprietorship are all sole proprietorships except for those listed as vocational or professional.

From a theoretical point of view, it is possible to describe this system as clear. However, there are several issues concerning establishing different kinds of sole proprietorships on the base of particular activities of the entrepreneurs.

Let us take an example of a person conducting masonry, which is the vocational sole proprietorship. The person's purpose of business activity is to build houses. In particular, there could be various problems in distinguishing between masonry and another vocational sole proprietorship, such as plumbing, heating, insulation, etc. The problem is that if a person is conducting a business that was not notified, that person is committing an administrative delict that could be punished by a financial fine up to $3319 €$.

Conducting unqualified sole proprietorship can also intervene with other types of sole proprietorships. For example, the List lists construction of buildings as unqualified sole proprietorship. According to our opinion, it is very hard to find the line between construction of buildings and the vocational sole proprietorships mentioned above.

It is also very difficult to set the differences between some professions and sole proprietorship. It is possible to find activities which can be the same in more professions. For example, the List names courier services as a 


\section{ENTREPRENEURSHIP AND SUSTAINABILITY ISSUES}

ISSN 2345-0282 (online) http://jssidoi.org/jesi/

2020 Volume 7 Number 4 (June)

http://doi.org/10.9770/jesi.2020.7.4(53)

possible unqualified sole proprietorship. This sole proprietorship can involve similar activities as entrepreneurs who conduct postal services under registration pursuant to Act No. 324/2011 Coll. on Postal Services as amended. Therefore, it is important to analyse the scope of activities that belong to the particular sole proprietorship. Another example: the List names administrative services as sole proprietorship. According to our opinion, this term is very general. It is hard to say if this sole proprietorship should include (for example) representation of particular persons in terms of various proceedings in front of state authorities. Representing persons in front of the state authorities could contain legal representation. However, such legal representation can interfere with conducting advocacy. Advocacy is one of the liberal professions and is regulated by the Act No. 586/2003 Coll. on Advocacy as amended (hereinafter only as Act on Advocacy).

The List contains activities that require professional skills. The unqualified sole proprietorships are, for example, provision of services in fisheries, quarrying of minerals, manufacture of wearing apparel, tanning and dressing of leather, manufacture of electrical equipment, etc., where an entrepreneur usually does not need to master professional skills.

We believe that legal regulation of sole proprietorship has to find the compromise between two basic values. The first value is the freedom to conduct a business. The second value is the consumer protection and environmental protection. The consumer protection includes protection of life, health and individual property. The consumer has to have a guaranty that products or provided services are of high quality and safety. Activities of entrepreneurs have to be friendly to environment also. Because of that the legal regulation of sole proprietorship in each state is responsible to its citizens. The legal regulation has to establish professional criteria for entrepreneurs for conducting sole proprietorship.

The criteria that are usually set for vocational and professional sole proprietorships are established in the special acts. For instance, Act on Advocacy establishes competences of attorneys in Art. 1 (2) through precisely defined activities. On the other hand, the Trade Licencing Act indicates only names (titles) of vocational sole proprietorship. Legal regulation of several professional sole proprietorships refers to the particular provisions that can be found in special acts. The List contains only short characteristics affiliated with particular unqualified sole proprietorships. In general, it is possible to say that the Trade Licencing Act identifies different kinds of sole proprietorship in the Slovak Republic only through their titles.

Such legal regulation is in breach with the principle of legal certainty. Entrepreneurs should also have the possibility to know the sole proprietorships not only through their titles, but also through defining particular activities that are "hidden" behind the title of the sole proprietorship. It is important because this issue influences the character of liability for unlawful activities of entrepreneurs. Based on that difference, criminal liability or administrative liability can be applied.

The authorities shall consider whether the activities fall under unqualified, vocational or professional sole proprietorship. The competent state authorities consider sole proprietorships according to their titles. Title of the particular sole proprietorship is important within the deciding-making process relating to liability for crimes or administrative delicts. This means that competent authorities have to interpret titles of sole proprietorships as indefinite terms.

If we talk about the business, we have to take into account many entrepreneurial activities. It would be ideal to make a list of them and define them. However, in legal practice, it is possible with only few of them. The development in this area is very fast and thereof any strict system of regulation would not be able to react to this development at ease. It would be easier to define only the vocational sole proprietorships and professional sole proprietorships. On the other hand, if we would define an exhausted list of unqualified sole proprietorships, it could cause restrictions to the freedom to conduct a business. The fast development is a call for the legislator. The 


\section{ENTREPRENEURSHIP AND SUSTAINABILITY ISSUES}

ISSN 2345-0282 (online) http://jssidoi.org/jesi/

2020 Volume 7 Number 4 (June)

http://doi.org/10.9770/jesi.2020.7.4(53)

legislator should be responsible for monitoring the market and should identify new services and products and include them into the list in order to set conditions upon them, or not.

\subsection{Analysis of unqualified trade}

In this part of the article we are focusing on only one type of sole proprietorships in the Slovak Republic unqualified sole proprietorship. If a person wants to conduct such sole proprietorship, he needs to fulfil only the general conditions laid down by the Trade Licencing Act and notify District Authority (Kohout, Horzinková, 1998). The professional qualification requirements are not stipulated when it comes to unqualified sole proprietorship (Skulová et al., 1999). The general conditions consist of

a) minimum age (a person must be 18 years old or older),

b) full legal capacity (a person fulfils this condition once reaching adulthood) and

c) being without criminal record (so called integrity; a person must not have committed any crime listed by Trade Licencing Act; these crimes are usually affiliated with conducting a business such as crimes against the right of property and business crimes; these crimes are defined by the Act No. 300/2005 Coll. Criminal Code as amended).

Unlike the unqualified trade, Trade Licensing Act stipulates qualification requirements only for vocational and professional sole proprietorship. Such requirements are a) educational; for conducting a sole proprietorship, one must usually have a bachelor/master degree from university, b) practice; one must have a practical experience in regards of the particular sole proprietorship; a person can gain practical skills under the supervision of a person already conducting the respective sole proprietorship; Trade Licencing Act usually requires a practice consisting of three or more years, or c) a combination of both aforementioned requirements.

We see that the requirements for professional and vocational sole proprietorships are more significant. The legislator stipulates them on a level that is more serious; the reason is that they require more adequate approach based on their respective specialization. This approach is required given the fact that the legislator is trying to protect customers' rights.

Since 1991 all requirements for sole proprietorships have been stipulated only in the Trade Licensing Act. The legislator helped to develop sole proprietorships in the Slovak Republic by doing so. Up until 1989 Slovak Republic was a part of the Czechoslovak Republic. The then state was under communist regime that oppressed and forbade any sole proprietorships or sole ownership therefore sole proprietorship did not exist. As of last year, that is not the truth anymore and requirements are stipulated in other statutes too.

On January 1, 2016, Act No. 246/2015 Coll. on Housing Management (hereinafter only as Housing Management Act) came to affect. Housing Management Act stipulates various conditions for administrators of housing management. According to this Act if a person wants to conduct housing management, he needs to fulfil general requirements stipulated in the Trade Licencing Act and notify his intent to conduct this business to the District Authority. This sole proprietorship is unqualified sole proprietorship as this business is included on the List. According to the List of Recommended Unqualified Trades and Their Descriptions, the housing management is a part of a trade called "Management and maintenance of residential and office premises" that is stipulated under entry No. 68.02.

However, unlike the Trade Licencing Act, the Housing Management Act also requires for the administrators to have a professional qualification. This professional qualification consists of educational requirements that subject to testing by independent educational institution. The educational institution must be licenced by the Ministry of Transport and Construction of the Slovak Republic. The test consists of questions on a) legislation on the housing 


\section{ENTREPRENEURSHIP AND SUSTAINABILITY ISSUES}

ISSN 2345-0282 (online) http://jssidoi.org/jesi/

2020 Volume 7 Number 4 (June)

http://doi.org/10.9770/jesi.2020.7.4(53)

management, b) administrative support on housing management, c) professional and technical issues concerning apartments and buildings, and d) management and financial management. A fee for the test is around $700 €$.

Now, we are facing a very interesting situation. On one hand, there is a general legal regulation that stipulates all aspects of sole proprietorships. From this point of view, Trade Licencing Act does not allow any exceptions from its regulation. Yet on the other hand, there is a special act that is contradicting the general act in terms of what conditions must be met to conduct a sole proprietorship of housing management.

We believe that this situation is in contradiction with the principle of legal certainty and principle of rule of law. It also represents a great obstacle to freedom to conduct a business not only from legal point of view, but also from business point of view. Legal rules should be clear, certain and understandable. Legal system of any state should be harmonic, meaning that one matter should be stipulated mainly in one statute only. If one matter could not be stipulated in one statue, then different statutes stipulating the same legal matter should be consistent and not in contradiction.

The Slovak Republic is a state that respects all the principles that altogether create a constant state of rule of law. If statutes are in contradiction, we should apply that regulation that is more convenient towards the recipients of the regulation. It is also a silent order for the legislator to amend the contradicting regulation.

\section{Conclusion}

The legal practice of District Authorities is very varied when it comes to unqualified sole proprietorships. It is a result of unbinding character of the List. Several District Authorities refuse to accept notification of unqualified sole proprietorship, although the sole proprietorship meets all conditions laid by the Trade Licencing Act. They refuse it on the grounds that this particular sole proprietorship is not named on the Ministry's List. On the other hand, several other District Authorities accept such notification. There is a great question of legal certainty when it comes to different legal practice in the same matters. Such legal practice is unacceptable. If legislation produces a state of legal uncertainty, the freedom to conduct a business is at stake. One of the unwanted legal obstacles to freedom to conduct business is when refusal of a notification of sole proprietorship is based on other than legal reasons.

Moreover, e.g. housing management is unqualified sole proprietorship according to the Trade Licencing Act and is included on the List meaning that only general conditions have to be met if a person wants to conduct such business. Nevertheless, the Housing Management Act requires for administrators of housing management to fulfil one special condition also, in concreto a special educational training. We believe that this cause unwanted discrepancy between statutes that stipulate the same subject matter. Moreover, in this particular case, these two statutes even contradict themselves. It is again a question of legal certainty. Taking this principle into account, we believe that the Trade Licencing Act should be amended and it should include housing management into a list of either vocational, or professional sole proprietorships.

Based on the analysis, we identified four measurements that have to be taken to prevent mentioned legal obstacles to freedom to conduct a business.

1) Special conditions to conduct sole proprietorship have to be laid down in accordance with the general act, i.e. by the Trade Licencing Act. By accepting this premise, we accept harmony in law also and in other words, we accept principle of legal certainty.

2) Trade Licencing Act should be more precise in defining distinctions between vocational and professional sole proprietorships based on the same reasoning as mentioned sub a). 


\section{ENTREPRENEURSHIP AND SUSTAINABILITY ISSUES}

ISSN 2345-0282 (online) http://jssidoi.org/jesi/

2020 Volume 7 Number 4 (June)

http://doi.org/10.9770/jesi.2020.7.4(53)

3) The List of Recommended Unqualified Sole Proprietorships and Their Descriptions on the webpage of the Ministry of Interior of the Slovak Republic should be updated more often; any new unqualified sole proprietorship should be listed based on legal practice of all District Authorities in the Slovak Republic.

4) Based on conclusion under c) Ministry of Interior of the Slovak Republic should organise trainings for District Authorities employees in order to secure consistency in proceedings concerning notifications of sole proprietorship.

\section{References}

Act No. 246/2015 Coll on. Housing Management

Act No. 324/2011 Coll. on Postal Services as amended

Act No. 586/2003 Coll. on Advocacy as amended

Begovič, B. 2018. Middle income convergence trap and the roll od competition policy in SEE countries. In: Compettition Authorities In South Eastern Europe. Springer Cham. ISBN 978-3-319-76643-0, pp 43-61.

Directive 2006/123/EC of the European Parliament and of the Council of 12 December 2006 on Services in the Internal Market. The Directive is implemented by Act No. 136/2010 Coll. On Services in the Internal Market that amended Act No. 455/1991 Coll. Trade Licensing Act.

European Union Agency for Fundamental Rights. (2015). Freedom to Conduct a Business: Exploring the Dimensions of a Fundamental Right. Luxembourg: Publications Office of the European Union.

Gurrrea-Martinéz, A, 2018. Re-examining the law and economics of the business judgment rule: Notes for its implementation in non-US jurisdiction. Journal of Corporate Law Studies, 18(2), 417-438. Print ISSN: 1473-5970 Online ISSN: 1757-8426.

Judgement of Court of Justice of the European Union, case 230/78, Eridania and others, 27 September 1979, paragraphs $20-22$.

Kohout, A., Horzinková E. (1998). Trade Act and related regulations. Praha: Linde. ISBN 80-7201-123-5

Lincényi, M., Čársky, J. 2020. Policy trusts in public policy in the Slovak Republic. Insights into Regional Development, 2(1), 456-468. http://doi.org/10.9770/IRD.2020.2.1(5)

Magurová, H. et al. (2016). Fundamentals of Law in Tourism for Economists. Bratislava: Wolters Kluwer. ISBN 978-80-8168-491-3

Ministry of Interior of the Slovak Republic (2016, 1 September). The List of Recommended Unqualified Sole Proprietorships and Their Descriptions http://www.minv.sk/?zivnostenske-podnikanie\&subor=40259

Petersen, N. 2013. Antitrust lawland the promotion of democracy and economic growth. Journal of Compatetition Law and Economics 9(3), 593-636, art. Nm.nth003. ISSN 1744-6414, EISSN 1744-6422

Škultéty, P. et al. (2002) Substantive, general and special administrative law. Bratislava: VO PraF UK. ISBN 80-7160-183-7

Škultéty, P. et al. (2008). Substantive, general and special administrative law. Bratislava: Vydavatel'ské oddelenie PraF UK. ISBN 978-807160-252-1

Sobihard, J. et al. (2010). Substantive administrative law, special part Žilina: Eurokódex. ISBN 978-80-8944-726-8

The List of Recommended Unqualified Sole Proprietorships and Their Descriptions http://www.minv.sk/?zivnostenskepodnikanie\&subor $=40259$ 


\section{ENTREPRENEURSHIP AND SUSTAINABILITY ISSUES}

ISSN 2345-0282 (online) http://jssidoi.org/jesi/

2020 Volume 7 Number 4 (June)

http://doi.org/10.9770/jesi.2020.7.4(53)

Vrabko, M. et al. (2012). Substantive, general and special administrative law. Bratislava: Vydavatel'ské oddelenie PraF UK. ISBN 978-807160-325-2-03-9

Vrabko, M. et al. (2015). Administrative procedural law, special part. Šamorín: Heuréka. ISBN 978-80-8173-007-8

\section{Acknowledgements}

This paper was supported by the project, which has received funding from the Grant Research Agency of the School of Economics and Management in Public Administration in Bratislava, of the Slovak Republic.

Mária SREBALOVA, Prof. JUDr. PhD. is an professor of administrative law of Law Faculty of Comenius University in Bratislava, Department of administrative and environmental law. Since 1994 she is a teacher and research worker in the fields of substantive administrative law and administrative procedural law. In 1999 she received a $\mathrm{PhD}$ degree and the dissertation thesis was focused on Selfgovernment in Slovak Republic. In 2018 she was awarded the title of Professor at the same school. Her monographs and scientific papers deal with the Public Administration, general administrative proceedings, asylum proceedings and offenses proceedings.

ORCID ID: https://orcid.org/0000-0002-9216-0081

Matej HORVAT, Assoc. Prof. JUDr. PhD., is an associate professor at the Department of Administrative and Environmental Law, Faculty of Law of Comenius University in Bratislava, Slovakia, where he graduated in 2009 and also received a PhD degree in 2012. Since 2019, he is an associate professor at the same faculty. His research activities focus on public administration, administrative proceeding, administrative punishment, right to a fair trial and freedom of information. He published books, monographs and scientific papers dealing with those topics. He attended and gave speeches on international scientific conferences in the CEE region.

ORCID ID: https://orcid.org/0000-0002-8249-4029

Juraj VAČOK, Assoc. Prof. JUDr., PhD. is an associated professor in the Department of Administrative and Environmental Law in Comenius University in Bratislava, Faculty of Law. He graduated the master studies in the 2006 and doctoral studies in the major administrative law in the year 2009 in this faculty (PhD.). His doctoral thesis is Administrative Justice. He defended his doctoral thesis „Participants of the Administrative Proceedings (JUDr.)” in the Year 2010. He was appointed for the associated professor in the year 2015. He focused in his research activities mainly to the administrative proceedings and administrative justice. He is co-author of university textbooks. He has been also the attorney's clerk since 2006. He lectured also in another high schools in the past.

ORCID ID: https://orcid.org/0000-0002-7490-6564 


\section{ENTREPRENEURSHIP AND SUSTAINABILITY ISSUES}

ISSN 2345-0282 (online) http://jssidoi.org/jesi/

2020 Volume 7 Number 4 (June)

http://doi.org/10.9770/jesi.2020.7.4(53)

František VOJTECH, Assoc prof. Ing. PhD is an associate professor at the School of Economics and Management in Public Administration in Bratislava. He graduated from the Military High School in Management (1978). In 2004 he received a PhD degree at the Faculty of Management at Comenius University in Bratislava. In 2018 he was awarded the title of Associate Professor at the same school. For more than 30 years he has been involved in various management and control functions in the state administration, and he is also teaching the Regional Policy of the European Union, the Strategy of Socio-Economic Development

ORCID ID: https://orcid.org/0000-0003-3099-0108

Stanislav FILIP, Assoc prof. Ing. PhD. is the Vice-Rector for foreign affairs an teacher of the School of Economics and management in Public Administration in Bratislava. His text books, monographs and scientific papers deal with the Risk and crisis management in public sector, international crisis management and public administration at the national and EU level. He is succesfull leader and manager of the several scientific projects with support from the EU structural funds. He also organise and control international colaboration and Erasmus plus program with the high educational and research institutions in abroad.

Researcher ID: F-7984-2017

ORCID ID: https://orcid.org/0000-0003-3000-9383

Copyright (C) 2020 by author(s) and VsI Entrepreneurship and Sustainability Center

This work is licensed under the Creative Commons Attribution International License (CC BY).

http://creativecommons.org/licenses/by/4.0/

cC) (i) Open Access 